Leila Motlagh, $\mathrm{PhD}$

Ralph Golbik, PhD

Wolfgang Sippl, PhD

Stephan Zierz, MD

Correspondence to

Dr. Motlagh:

leila.motlagh@medizin.uni-halle.de

\section{Stabilization of the thermolabile variant S113L of carnitine palmitoyltransferase II}

OPEN

Objective: Muscle carnitine palmitoyltransferase (CPT) II deficiency, the most common defect of lipid metabolism in muscle, is characterized by attacks of myoglobinuria without persistent muscle weakness.

Methods: $\mathrm{His}_{6}-\mathrm{N}-h \mathrm{CPT} 2$ (wild-type) and $\mathrm{His}_{6}-\mathrm{N}-\mathrm{hCPT} 2 / \mathrm{S} 113 \mathrm{~L}$ (variant) were produced recombinantly in prokaryotic host and characterized according to their functional and regulatory properties.

Results: The wild-type and the variant S113L showed the same enzymatic activity and thermostability at $30^{\circ} \mathrm{C}$. The mutated enzyme, however, revealed an abnormal thermal destabilization at $40^{\circ} \mathrm{C}$ and $45^{\circ} \mathrm{C}$. This was consistent with an increased flexibility (B-factor) of the variant at $40^{\circ} \mathrm{C}$ compared with that of the wild-type shown by molecular dynamics analysis. Preincubation of the enzymes with L-carnitine and acyl-L-carnitines containing more than 10 carbons in the acyl sidechain stabilized the mutated enzyme against thermal inactivation. In contrast, palmitoyl-CoA destabilized both enzymes.

Conclusions: The problems in CPT II deficiency originating from the S113L mutation are not caused by the loss of catalytically active enzyme. They might be at least partially related to an impaired thermal stability of the protein. The lower thermodynamic stability of the variant might explain why fever and prolonged exertion provoke attacks of myoglobinuria in CPT II deficiency. The stabilization by acyl-L-carnitines might provide the basis for possible preventive therapy of CPT II deficiency. Neurol Genet 2016;2:e53; doi: 10.1212/NXG.0000000000000053

\title{
GLOSSARY
}

CPT = carnitine palmitoyltransferase; LB-medium = LURIA-BERTANI medium; MD = molecular dynamics; RMSD = rootmean-square deviation.

Carnitine palmitoyltransferase (CPT) II deficiency is regarded as the most common defect of lipid metabolism in skeletal muscle. ${ }^{1}$ There are 3 phenotypes of CPT II deficiency: (1) a lethal neonatal form, (2) a severe infantile hepatocardiomuscular form, and (3) a mild myopathic form. ${ }^{2}$ The symptoms of the latter usually consist of recurrent attacks of myalgia and muscle weakness leading to myoglobinuria, which might result in kidney failure. The attacks are provoked by prolonged exercise, fasting, fever, or exposure to cold. ${ }^{3}$

The mutation S113L has been found on at least 1 allele in about $90 \%$ of patients with muscle CPT II deficiency (allele frequency about $75 \%$ ). ${ }^{3}$

Biochemical consequences of the mutation S113L are still controversial and comprise the following hypotheses:

1. Reduced enzyme activity with normal or reduced protein content. ${ }^{4,5}$

2. Abnormally regulated enzyme rather than a reduced catalytic activity. ${ }^{6-8}$

3. Decreased protein stability leading to a marked reduction in the steady-state level of the enzyme., ${ }^{9,10}$

4. Decreased thermal stability. ${ }^{4}$

Supplemental data at Neurology.org/ng

From the Department of Neurology (L.M., S.Z.), Institute of Biochemistry and Biotechnology (R.G.), and Institute of Pharmacy (W.S.), Martin Luther University Halle-Wittenberg, Halle (Saale), Germany.

Funding information and disclosures are provided at the end of the article. Go to Neurology.org/ng for full disclosure forms. The Article Processing Charge was paid by the authors.

This is an open access article distributed under the terms of the Creative Commons Attribution-NonCommercial-NoDerivatives License 4.0 (CC BY-NC-ND), which permits downloading and sharing the work provided it is properly cited. The work cannot be changed in any way or used commercially. 
Figure 1 Effector-mediated thermal inactivation of carnitine palmitoyltransferase II (considering only 1 binding site of the effector)

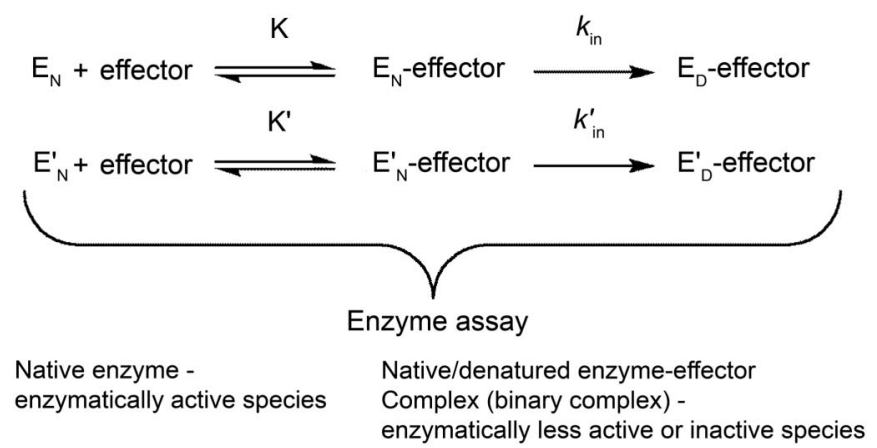

E represents the wild-type, $\mathrm{E}^{\prime}$ the variant $\mathrm{S} 113 \mathrm{~L}, \mathrm{~N}$ the native state, $\mathrm{D}$ the denatured state, $\mathrm{K}$ the equilibrium constant of the initial enzyme-effector binary complex, and $k_{\text {in }}$ the microscopic first-order rate constant of the inactivation. The apostrophe indicates the parameters of the variant.
$(3 \times 5 \mathrm{~mL}$ His-Trap columns). The bound target protein carrying a His-tag was eluted using an imidazole gradient. Recombinant CPT II was further purified by gel filtration on Superdex S $200(26 / 60)$ and finally by ion-exchange chromatography on Q-Sepharose HP (10/16) according to supplier's recommendations. The purification was verified by SDS-PAGE and protein identity was confirmed by mass spectrometry.

Enzyme assay of CPT II. CPT II activity was determined spectroscopically according to Rufer et al. ${ }^{11}$ with some modifications. The assay is based on the reduction of 5,5'-dithio-bis-(2nitrobenzoic acid) by $\mathrm{CoA}-\mathrm{SH}$ and subsequent formation of 5-mercapto-2-nitrobenzoic acid, which absorbs at $410 \mathrm{~nm}$ with a molar extinction coefficient of $13,600 / \mathrm{M} / \mathrm{cm} .{ }^{12}$ The formation of CoA-SH was monitored by addition of CPT II to a solution containing L-carnitine and palmitoyl-CoA. The $1-\mathrm{mL}$ reaction volume contained $50 \mathrm{mM}$ potassium phosphate, $120 \mathrm{mM} \mathrm{KCl}$, $1 \mathrm{mM}$ ethylenediaminetetraacetic acid (EDTA), $1 \mathrm{mM} \mathrm{5,5^{ \prime } -}$ dithio-bis-(2-nitrobenzoic acid), $30 \mu \mathrm{M}$ palmitoyl-CoA, and 12 $\mathrm{mM}$ L-carnitine ( $\mathrm{pH}$ 7.4). After temperature equilibration, the reaction was initiated by the addition of recombinant enzyme to a final concentration of $15 \mathrm{nM}$ and monitored for 120 seconds. Activity measurements were conducted at $25^{\circ} \mathrm{C}$.

All previous studies dealing with CPT II are based on experiments using vertebrate enzyme or human cell lysate. The present work on the recombinant enzymes $\mathrm{His}_{6}-\mathrm{N}-h \mathrm{CPT} 2$ and His $_{6}-\mathrm{N}-h \mathrm{CPT} 2 / \mathrm{S} 113 \mathrm{~L}$ evaluates their thermal stability.

METHODS Recombinant production and purification of human CPT II (wild-type and variant S113L). The genes coding for wild-type enzyme $\left(\mathrm{His}_{6}-\mathrm{N}-h \mathrm{CPT} 2\right)$ and the most prominent variant of CPT II deficiency, S113L $\left(\mathrm{His}_{6}-\mathrm{N}\right.$ hCPT2/S113L), were created by site-directed mutagenesis from the gene coding for the triple variant $\left(\mathrm{His}_{6}-\mathrm{N}-h \mathrm{CPT} 2 / \mathrm{S} 113 \mathrm{~L} /\right.$ $\mathrm{V} 368 \mathrm{I} / \mathrm{M} 647 \mathrm{~V}$ ). The genes were then cloned into (pET28a $(+))$. The plasmids were transformed into chemo-competent Escherichia coli BL21Gold DE3 cells, and the recombinant protein was realized by heterologous gene expression in the prokaryotic host. Cells carrying the plasmids were grown in LURIA-BERTANI medium (LB-medium) supplemented with kanamycin $(30 \mu \mathrm{g} / \mathrm{mL})$ in a preculture overnight at $37^{\circ} \mathrm{C}$. After centrifugation $\left(30\right.$ minutes at $6,000 \mathrm{rpm}$ at $10^{\circ} \mathrm{C}$ ), cells were resuspended in fresh LB-medium for inoculation of 5-L sterile LB-medium supplemented with kanamycin $(30 \mu \mathrm{g} / \mathrm{mL})$ in a Biostat C-DCU 3 fermenter (B. Braun Biotech International $\mathrm{GmbH}$, Melsungen, Germany). Cells were grown at oxygen content of $25-30 \%$ and feeding control (yeast extract, glycerol) for 10 hours. Gene expression was induced by adding isopropyl$\beta$-D-thiogalactopyranoside (IPTG) $(1 \mathrm{mM})$, and recombinant protein was produced for about 12-14 hours. Cells were then harvested by centrifugation $\left(30\right.$ minutes at $6,000 \mathrm{rpm}$ and $10^{\circ} \mathrm{C}$ ) and shock frozen in liquid nitrogen. One hundred grams of frozen cells were thawed in suspension buffer $(50 \mathrm{mM} 4-(2-$ hydroxyethyl)-1-piperazineethanesulfonic acid [HEPES], 150 $\mathrm{mM} \mathrm{NaCl}, 3 \mathrm{mM}$ tris (2-chloroethyl) phosphate [TCEP], 10 $\mathrm{mM} \mathrm{MgCl} 2,3 \mathrm{mM}$ benzamidine, $1 \mu \mathrm{g} / \mathrm{mL}$ leupeptine, $0.7 \mu \mathrm{g} /$ $\mathrm{mL}$ pepstatin $\mathrm{A}, \mathrm{pH} 8.0)$ and lysed by adding lysozyme $(50 \mu \mathrm{g} /$ $\mathrm{mL}$ ) using a French Press at 1,200 bar. Nucleic acids were digested by incubation of DNase I. After centrifugation of the lysed cells ( 45 minutes at $45,000 \mathrm{rpm}$ and $4^{\circ} \mathrm{C}$, using a 45 Ti rotor in a Beckman L8-60M ultracentrifuge [Beckman Instruments Inc., Brea, CA]), the supernatant was directly applied to a Ni-nitrilotriacetic acid (NTA) affinity chromatography column
Thermal and effector-mediated inactivation of CPT II. The temperature transitions (melting curves) of recombinant CPT II wild-type and the variant S113L were measured by circular dichroism at $210 \mathrm{~nm}$ in $25 \mathrm{mM}$ phosphate buffer $(\mathrm{pH}$ 8.0) containing $50 \mathrm{mM} \mathrm{NaCl}$ and $2 \mathrm{mM}$ TCEP.

Data of effector-mediated and temperature-induced inactivation of CPT II were investigated according to the reaction scheme depicted in figure 1 considering a negligible reactivation of the inactivated enzyme only.

The decrease of the enzymatic activity was analyzed according to a single-exponential first-order reaction using equation 1 , yielding the apparent rate constant of inactivation:

$$
\begin{aligned}
& \mathrm{A}=\mathrm{A}_{0} \cdot \exp \left(-k_{\text {app }} \cdot \mathrm{t}\right) \\
& k_{\text {app }}=k_{\text {in }}+k_{\text {re }} \\
& \lim \left(k_{\text {re }}\right) \rightarrow 0
\end{aligned}
$$

where $\mathrm{A}$ is the residual activity of the enzyme measured at time $\mathrm{t}$ of inactivation, $\mathrm{A}_{0}$ is the initial activity of the enzyme, $k_{\mathrm{in}}$ is the first-order rate constant of inactivation, $k_{\mathrm{re}}$ is the first-order rate constant of reactivation, and $k_{\text {app }}$ is the apparent first-order rate constant of inactivation. The apparent rate constants of inactivation were determined by fitting the time course of the change of the enzymatic activities according to equation 1 using the program Kaleidagraph. For better data investigation and comparison, the activity changes were evaluated as a percentage of total initial activity (relative activities). Fitting parameters are presented with mean square errors.

Simultaneous incubation with palmitoyl-L-carnitine. To evaluate the stabilizing effect of palmitoyl-L-carnitine on CPT II, the activities of $\mathrm{His}_{6}-\mathrm{N}-h \mathrm{CPT} 2$ and $\mathrm{His}_{6}-\mathrm{N}-h \mathrm{CPT} 2 / \mathrm{S} 113 \mathrm{~L}$ were measured in the presence of $25 \mu \mathrm{M}$ palmitoyl-L-carnitine in the reaction mixture.

Preincubation with acyl-CoA and acyl-L-carnitine derivatives. To evaluate a putative substrate protection effect on the kinetic stability of the enzymes before activity measurements, $\mathrm{His}_{6}-\mathrm{N}-h \mathrm{CPT} 2$ and $\mathrm{His}_{6}-\mathrm{N}-h \mathrm{CPT} 2 / \mathrm{S} 113 \mathrm{~L}$ were preincubated with the indicated amounts of $\mathrm{L}$-carnitine or palmitoyl-CoA at $30^{\circ} \mathrm{C}, 40^{\circ} \mathrm{C}$, and $45^{\circ} \mathrm{C}$ in different series of experiments. Acyl-Lcarnitines (C2, C4, C5, C6, C8, C10, C12, C14, and C16) at a concentration of $25 \mu \mathrm{M}$ were preincubated with the wild-type or the mutated enzyme at $40^{\circ} \mathrm{C}$ and $45^{\circ} \mathrm{C}$, respectively. Activity measurements were performed after different incubation times. 
Computational methods. Homology modeling. A homology model of human CPT II was built using the crystal structure of rat CPT II (PDB code $2 \mathrm{DEB})^{11}$ as a template. Sequence alignment of both proteins (aa 32-658 showing 95.2\% sequence identity) was performed using the molecular modeling package Molecular Operating Environment (Chemical Computing Group, Montreal, Quebec, Canada). ${ }^{13}$ The program MODELLER9v1 $11^{14}$ was used to generate the homology model and the model of the variant $\mathrm{S} 113 \mathrm{~L}$.

Molecular dynamics. The sander module in AMBER12 $2^{15}$ was applied for the energy minimization steps, whereas ParticleMesh-Ewald molecular dynamics (MD) was used for the MD simulation. Particle-Mesh-Ewald method was used to treat electrostatic interactions, and a cut-off radius of $10 \AA$ was set for nonbonded interactions. Preparation of the input files was conducted as follows. The General Amber Force Field with AM1BCC charges was applied to assign atom types to the ligands (palmitoyl-L-carnitine), whereas Amber03 force field was used for the protein. The protein or protein-acyl-L-carnitine complexes were solvated in an octahedral box of TIP3P water with $13 \AA$ between the complex surface and the box boundary, and counter ions were added to neutralize the system. The solvated system was then subjected to 3 steps of energy minimization: a 1,600step minimization (800 cycles of steepest descent followed by 800 cycles of conjugate gradient) while keeping the solute fixed by a force of $10 \mathrm{kcal} / \mathrm{mol} / \AA \AA$; 1,600 cycles of minimization using 800 -step steepest descent and subsequent 800 -step conjugate gradient while keeping the solute fixed by a force of $2 \mathrm{kcal} / \mathrm{mol} / \AA$; and a 2,000-step minimization (1,000-step steepest descent and 1,000 -step conjugate gradient). The system was gradually heated to the studied temperature $(277 \mathrm{~K}, 299 \mathrm{~K}$, and $313 \mathrm{~K})$ over 100 picoseconds, and then a 22-nanosecond MD simulation was performed in the NPT ensemble (pressure 1.0 bar and temperature $300 \mathrm{~K}$ ). During MD, all covalent bonds involving $\mathrm{H}$-atoms were constrained using the SHAKE procedure, and the time step was set to 2 femtoseconds. The root-mean-square deviation (RMSD) of the backbone atoms of the protein was calculated using the input structure as reference. The B-factor for the backbone of the protein residues was calculated using the program ptraj from AMBER12 over the 22-nanosecond MD simulation.

Docking studies. The human CPT II homology model was used for molecular docking studies. First, we tested whether the docking program GOLD ${ }^{16}$ was able to redock the cocrystallized ligands in the CPT II and carnitine acetyltransferase crystal structures taken from the Protein Database (2RCU, 4EP9, 1TQ7). Good agreement between experimental and docking structures with RMSD values below $1.5 \AA$ was obtained.

RESULTS Activities of recombinant CPT II. The expression of recombinantly produced human CPT II wild-type and its variant S113L was confirmed by mass spectrometry and their structural integrity was proven by enzymatic assays. At $30^{\circ} \mathrm{C}$, both the wildtype and the variant $\mathrm{S} 113 \mathrm{~L}$ displayed similar specific activities of at least 39 and $33 \mathrm{U} / \mathrm{mg}$, respectively.

Thermal inactivation of CPT II. At $30^{\circ} \mathrm{C}$, both enzymes exhibited the same thermal stability; however, the incubation of the enzymes at $40^{\circ} \mathrm{C}$ and at $45^{\circ} \mathrm{C}$ (figure 2) resulted in a considerably faster inactivation of the mutated enzyme compared with the wild-type at both temperatures.
Figure 2 Thermal inactivation of $\mathrm{His}_{6}-\mathrm{N}-\mathrm{hCPT} 2$ and $\mathrm{His}_{6}-\mathrm{N}-\mathrm{hCPT} 2 / \mathrm{S} 113 \mathrm{~L}$ at different temperatures

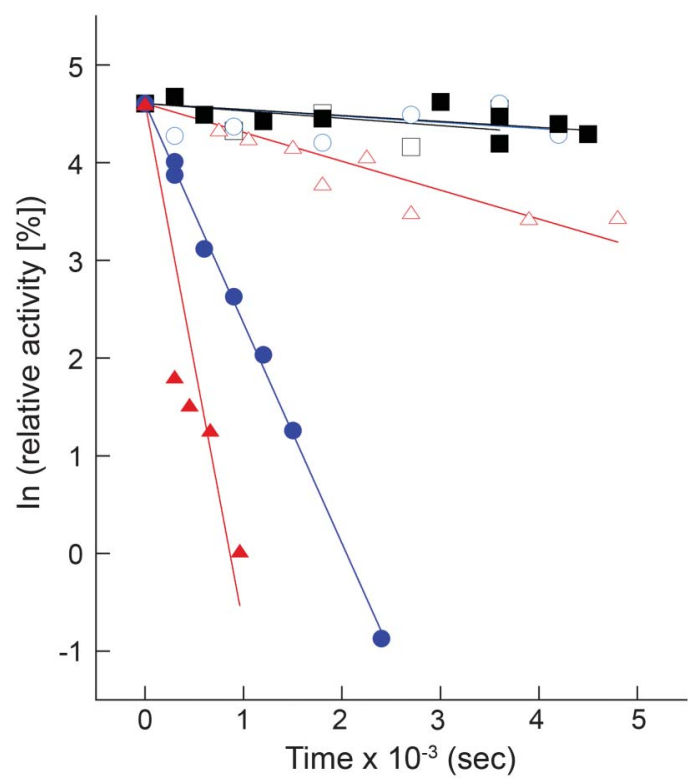

Black squares, blue circles, and red triangles represent values at $30^{\circ} \mathrm{C}, 40^{\circ} \mathrm{C}$, and $45^{\circ} \mathrm{C}$, respectively. Open symbols show the wild-type recombinant carnitine palmitoyltransferase II and the closed symbols show $\mathrm{His}_{6}-\mathrm{N}-\mathrm{hCPT} 2 / \mathrm{S} 113 \mathrm{~L}$. Data are presented as time-dependent changes of naturallog-transformed relative activities. The experiments were performed as explained in the Methods section.

The thermal denaturation of the proteins turned out to be irreversible. Hence, with the transition midpoint dependent on the protein concentration, no thermodynamic parameters of thermal equilibrium unfolding could be determined. During thermal unfolding, no aggregation and precipitation of the proteins occurred in the unfolded state at elevated temperatures, which was indicated by the photomultiplier voltage of the dichrograph and by light scattering (data not shown).

MD simulations were performed to study the stability of the wild-type and the variant $\$ 113 \mathrm{~L}$ at 3 different temperatures: $4^{\circ} \mathrm{C}(277 \mathrm{~K}), 20^{\circ} \mathrm{C}(293$ $\mathrm{K})$, and $40^{\circ} \mathrm{C}(313 \mathrm{~K})$. For this purpose, the generated homology model of human CPT II was used. To assess the thermal stability of the enzyme, the RMSD of the protein backbone (figure e-1 at Neurology.org/ng) and the B-factor (indicating the flexibility of the backbone) over the length of the MD simulation were measured. MD simulations showed that the calculated B-factor for the residues neighboring the mutation site (S110-L121) reveal in a considerably higher fluctuation for the mutant's residues at $313 \mathrm{~K}\left(40^{\circ} \mathrm{C}\right)$ compared with $277 \mathrm{~K}$ $\left(4^{\circ} \mathrm{C}\right)$ and to a lesser extent with $293 \mathrm{~K}\left(20^{\circ} \mathrm{C}\right)$. This could be indicative of the lower thermal stability of the mutated enzyme at $40^{\circ} \mathrm{C}$. Conversely, 
the calculated B-factor for the wild-type did not show any noticeable differences at the 3 temperatures studied (figure 3A). The hydroxyl group of S113 can form several H-bond interactions. These include a water-mediated H-bond with $\mathrm{R} 498$ as found in the homology model or an H-bond interaction with the backbone carbonyl group of H496 (figure 3B). The reason behind the instability of the variant S113L might be the inability of L113 to form these H-bonds, which would induce conformational changes, especially at the residues neighboring the mutation site.

Figure 3 Flexibility of carnitine palmitoyltransferase (CPT) II studied by molecular dynamics simulation

A

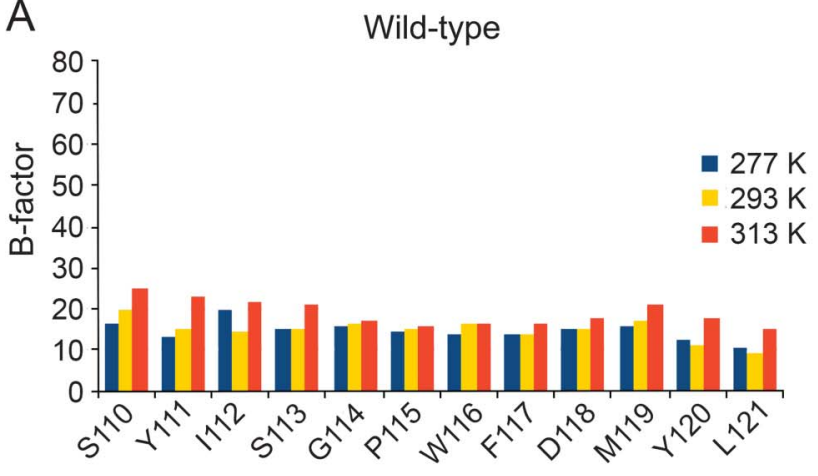

Residue ID

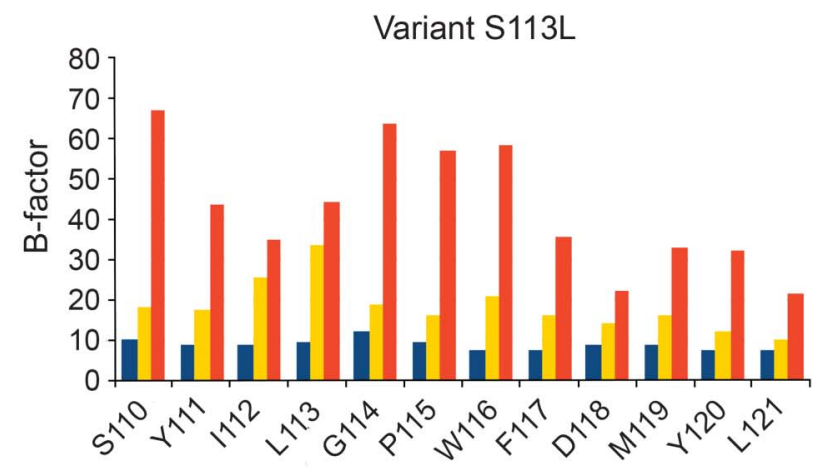

Residue ID

B

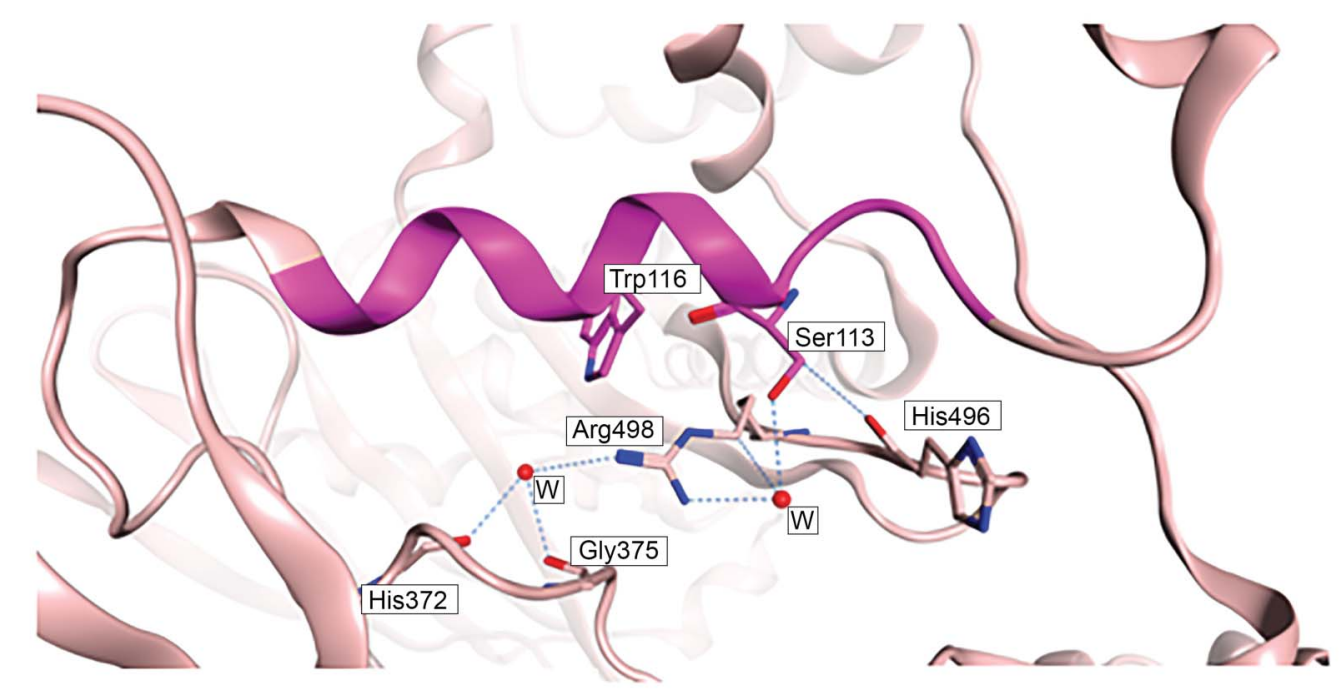

C

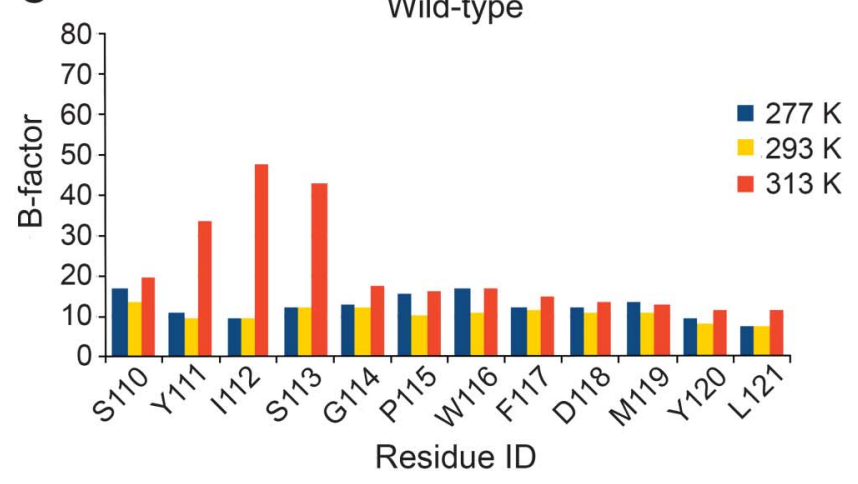

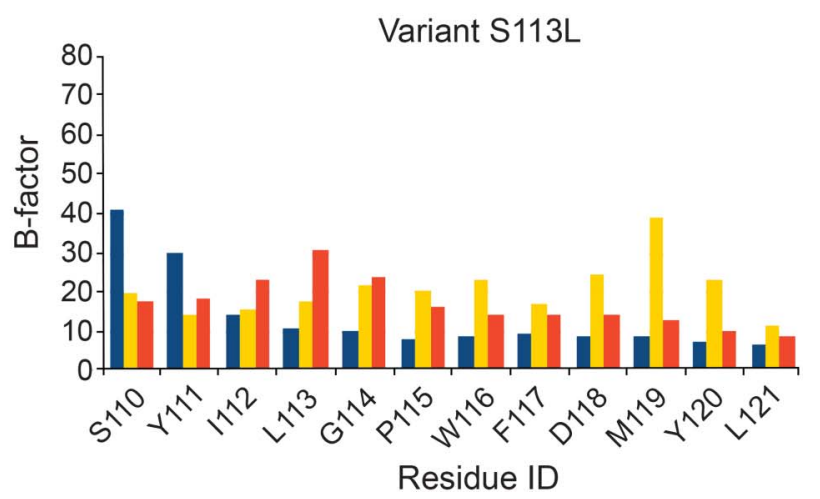

(A) B-factors of residues S110-L121 of CPT II calculated over 22 nanoseconds of MD simulation of wild-type (left) and the variant S113L (right) at 277 K, $293 \mathrm{~K}$, and $313 \mathrm{~K}$. (B) S113 (magenta) forms H-bond interactions with neighboring residues as seen in the generated homology model of human CPT II. The $\alpha$-helix-bearing residue $\mathrm{S} 113$ is shown as magenta ribbon, and the rest of the enzyme is shown as pink ribbon. $\mathrm{H}$-bond interactions are shown as blue dotted lines. Water molecules are depicted as red balls. (C) B-factors of residues S110-L121 of CPT II were calculated over 22 nanoseconds of MD simulation for the wild-type (left) and the variant S113L (right) in complex with palmitoyl-L-carnitine at $277 \mathrm{~K}, 293 \mathrm{~K}$, and $313 \mathrm{~K}$. 
Figure 4 Effect of substrates on kinetic stability of recombinant carnitine palmitoyltransferase (CPT) II enzymes
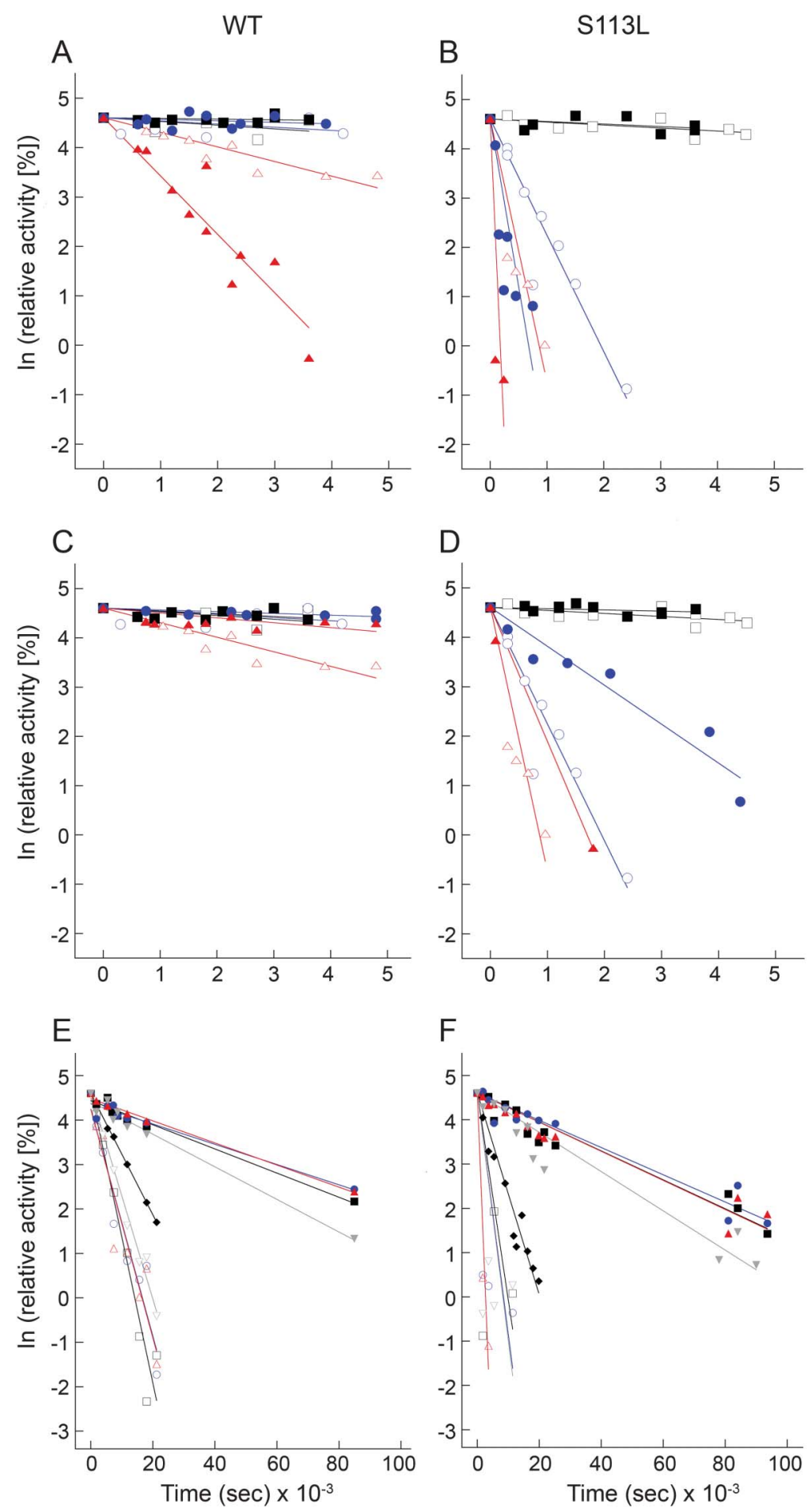

A and $B$ show the heat inactivation of $\mathrm{His}_{6}-\mathrm{N}-h \mathrm{CPT} 2$ and $\mathrm{His}_{6}-\mathrm{N}-\mathrm{hCPT} 2 / \mathrm{S} 113 \mathrm{~L}$, respectively, at different temperatures supported by palmitoyl-CoA. $C$ and $D$ show the heat inactivation of $\mathrm{His}_{6}-\mathrm{N}-\mathrm{hCPT} 2$ and $\mathrm{His}_{6}-\mathrm{N}-\mathrm{hCPT} 2 / \mathrm{S} 113 \mathrm{~L}$, respectively, at different temperatures suppressed by L-carnitine. Black squares, blue circles, and red triangles represent values at $30^{\circ} \mathrm{C}, 40^{\circ} \mathrm{C}$, and $45^{\circ} \mathrm{C}$, respectively. Open and closed symbols show the results of experiments performed in the absence or in the presence of palmitoyl-CoA or L-carnitine, respectively. $\mathrm{E}$ and $\mathrm{F}$ present the stabilization of $\mathrm{His}_{6}-\mathrm{N}-h \mathrm{CPT} 2$ and $\mathrm{His}_{6}-\mathrm{N}-\mathrm{hCPT} 2 / \mathrm{S} 113 \mathrm{~L}$, respectively, against heat inactivation by preincubation with acyl-L-carnitines at $45^{\circ} \mathrm{C}$. Black open squares, blue open circles, red open triangles, gray open inverted triangles, black closed diamonds, black closed squares, blue closed circles, red closed triangles, and gray closed inverted triangles represent acetyl-L-carnitine (C2), isobutyryl-L-carnitine (C4), valeryl-L-
Effects of substrates on thermal inactivation of CPT II. The kinetic stability of the enzymes was measured after their preincubation with various substrates at different temperatures.

Destabilization by palmitoyl-CoA. Preincubation of $\mathrm{His}_{6}-\mathrm{N}-h \mathrm{CPT} 2$ and $\mathrm{His}_{6}-\mathrm{N}-h \mathrm{CPT} 2 / \mathrm{S} 113 \mathrm{~L}$ with the native substrate palmitoyl-CoA before the addition of L-carnitine generally increased the rate constants of thermal inactivation at $40^{\circ} \mathrm{C}$ and $45^{\circ} \mathrm{C}$ and revealed no substrate protection. At both temperatures, the thermal inactivation was faster in the variant than in wild-type (figure $4, \mathrm{~A}$ and $\mathrm{B}$; table).

Effects of L-carnitine and acyl-L-carnitines. Simultaneous addition of palmitoyl-L-carnitine. The presence of additional palmitoyl-L-carnitine at $25 \mu \mathrm{M}$ in the assay mixture had no effect on the enzyme activity. The simultaneous addition of higher concentrations of palmitoyl-L-carnitine as 1 product of the forward CPT II assay reaction progressively inhibited both enzymes. This inhibition, however, was much stronger for the variant S113L than for the wild-type. The residual activity of the variant $S 113 \mathrm{~L}$ in the presence of $200 \mu \mathrm{M}$ palmitoyl-L-carnitine was only $60 \%$ that of the wild-type under the same conditions.

Preincubation with L-carnitine and acyl-L-carnitines. Both the wild-type and the mutated recombinant enzyme displayed a much higher kinetic stability on preincubation with L-carnitine at $45^{\circ} \mathrm{C}$ (figure $4, \mathrm{C}$ and D; table).

The short-chain acyl-L-carnitines C2, C4, C5, and C6 showed a slight stabilizing effect on $\mathrm{His}_{6^{-}}$ $\mathrm{N}-h \mathrm{CPT} 2$ and $\mathrm{His}_{6}-\mathrm{N}-h \mathrm{CPT} 2 / \mathrm{S} 113 \mathrm{~L}$ at $45^{\circ} \mathrm{C}$ (figure 4, E and F; table). The middle-chain acylL-carnitines C10, C12, and C14 and the long-chain C16 stabilized the mutated enzyme to the level of the wild-type. Thus, the inactivation rate constants of $\mathrm{His}_{6}-\mathrm{N}-h \mathrm{CPT} 2 / \mathrm{S} 113 \mathrm{~L}$ were smaller by a factor of about 150 at $45^{\circ} \mathrm{C}$. Octanoyl-L-carnitine (C8) displayed an intermediate stabilizing effect on both enzymes against thermal inactivation (figure 4, E and F; table).

The acyl-L-carnitines with the most pronounced stabilizing effect on the enzymes were also tested at $40^{\circ} \mathrm{C}$. Here, the acyl-L-carnitines C10, C12, C14, and $\mathrm{C} 16$ decreased the inactivation rate constant of $\mathrm{His}_{6}-\mathrm{N}-h \mathrm{CPT} 2 / \mathrm{S} 113 \mathrm{~L}$ and $\mathrm{His}_{6}-\mathrm{N}-h \mathrm{CPT} 2$ by a

carnitine (C5), hexanoyl-L-carnitine (C6), octanoyl-L-carnitine (C8), decanoyl-L-carnitine (C10), lauroyl-L-carnitine (C12), myristoyl-L-carnitine (C14), and palmitoyl-L-carnitine (C16), respectively. Data are presented as time-dependent changes of natural-log-transformed relative activities. The experiments were performed as explained in the Methods section. S113L = the variant S113L; WT = wild-type. 


\begin{tabular}{|c|c|c|c|c|c|c|}
\hline \multicolumn{7}{|c|}{ recombinant $h C P T 2$ proteins in the presence of substrates at different temperatures } \\
\hline \multicolumn{2}{|l|}{ Effector } & \multirow[b]{2}{*}{$\begin{array}{l}\text { Concentration, } \\
\mu \mathrm{M}\end{array}$} & \multicolumn{2}{|l|}{$\mathrm{His}_{6}-\mathrm{N}-\mathrm{hCPT2}$} & \multicolumn{2}{|c|}{$\mathrm{His}_{6}-\mathrm{N}-\mathrm{hCPT} 2 / \mathrm{S} 113 \mathrm{~L}$} \\
\hline Name & $\begin{array}{l}\text { No. of carbon } \\
\text { atoms in acyl chain }\end{array}$ & & $\begin{array}{l}k_{\text {app }} 10^{-5}\left(\mathrm{~s}^{-1}\right) \\
\text { at } 40^{\circ} \mathrm{C}\end{array}$ & $\begin{array}{l}k_{\text {app }} 10^{-5}\left(s^{-1}\right) \\
\text { at } 45^{\circ} \mathrm{C}\end{array}$ & $\begin{array}{l}k_{\text {app }} 10^{-5}\left(\mathrm{~s}^{-1}\right) \\
\text { at } 40^{\circ} \mathrm{C}\end{array}$ & $\begin{array}{l}k_{\text {app }} 10^{-5}\left(\mathrm{~s}^{-1}\right) \\
\text { at } 45^{\circ} \mathrm{C}\end{array}$ \\
\hline No effector & & & $6.4 \pm 3.3$ & $29.5 \pm 2.4$ & $225.2 \pm 2.7$ & $534.9 \pm 58.1$ \\
\hline Palmitoyl-L-CoA & 16 & 30 & $3.1 \pm 1.9$ & $118.1 \pm 7.9$ & $680.1 \pm 113.2$ & $>700$ \\
\hline L-Carnitine & No acyl residue & 12,000 & $3.6 \pm 0.7$ & $9.9 \pm 2.2$ & $78.7 \pm 5.9$ & $271.5 \pm 16.5$ \\
\hline Acetyl-L-carnitine & 2 & 25 & ND & $32.6 \pm 1.7$ & ND & $46.8 \pm 21.4$ \\
\hline Isobutyry|-L-carnitine & 4 & 25 & ND & $27.9 \pm 1.8$ & ND & $54.5 \pm 19.7$ \\
\hline Valeryl-L-carnitine & 5 & 25 & ND & $28.1 \pm 2.0$ & ND & $173.2 \pm 20.7$ \\
\hline Hexanoyl-L-carnitine & 6 & 25 & ND & $23.2 \pm 0.7$ & ND & $56.0 \pm 19.4$ \\
\hline Octanoyl-L-carnitine & 8 & 25 & ND & $13.7 \pm 0.1$ & ND & $22.8 \pm 0.9$ \\
\hline Decanoyl-L-carnitine & 10 & 25 & $0.29 \pm 0.02$ & $3.0 \pm 0.2$ & $0.24 \pm 0.02$ & $3.3 \pm 0.2$ \\
\hline Lauroyl-L-carnitine & 12 & 25 & $0.26 \pm 0.02$ & $2.7 \pm 0.3$ & $0.18 \pm 0.02$ & $3.1 \pm 0.2$ \\
\hline Myristoyl-L-carnitine & 14 & 25 & $0.24 \pm 0.02$ & $2.7 \pm 0.2$ & $0.24 \pm 0.01$ & $3.3 \pm 0.2$ \\
\hline Palmitoyl-L-carnitine & 16 & 25 & $0.27 \pm 0.02$ & $4.0 \pm 0.3$ & $0.23 \pm 0.01$ & $4.4 \pm 0.3$ \\
\hline
\end{tabular}

Abbreviation: $\mathrm{ND}=$ not determined.

Enzymes were preincubated with the respective substrate at the indicated temperatures. The rate constants of inactivation were determined from fitting of the time-dependent decrease of the enzymatic activity as described in the Methods section.

factor of about 1,000 and 25 , respectively. At $40^{\circ} \mathrm{C}$, the mutated enzyme showed a very similar kinetic stability as the wild-type in the presence of these acyl-L-carnitines (table).

MD studies on CPT II in complex with palmitoyl-L-carnitine showed similar behavior of the wild-type and the variant $5113 \mathrm{~L}$ with respect to temperature. The B-factor of the residues of the mutant surrounding the mutation site did not show any increase at higher temperature $\left(313 \mathrm{~K}, 40^{\circ} \mathrm{C}\right)$ (figure 3C). Generally, the flexibility of the mutation site (S110-L121) of the acyl-L-carnitine-binding site (figures e-2 and e-3) and of the whole protein (figure e-1) was lower for the complex of the variant $S 113 \mathrm{~L}$ with palmitoyl-L-carnitine than for the protein without substrate at $313 \mathrm{~K}$.

DISCUSSION The enzymatic activities of the recombinant wild-type CPT II and its variant S113L were similar. This shows that the hypothesis of reduced enzyme activity (deficiency) of the S113L variant can no longer be maintained. This is consistent with the clinical observation that patients harboring the S113L mutation show only attacks of muscle weakness and myoglobinuria but no persistent or progressive muscle weakness (in contrast to Lcarnitine-deficient patients). This is also consistent with recent findings of normal protein concentrations of the CPT II variant in skeletal muscle, ${ }^{7}$ indicating that there is no decreased steady-state level of the protein, as previously suggested. ${ }^{9}$ The phenotype of the S113L mutation restricted to muscle without any other organ involvement indicates that a mutant enzyme can be variously represented and function in vivo in various tissues.

Between the attacks, the patients have no symptoms of myalgia and muscle weakness. This is consistent with the findings of the normal activity and stability of the variant at body temperature. Attacks of myoglobinuria in CPT II deficiency are usually provoked by fever, infections, fasting, prolonged physical stress, and exposure to cold. All of these trigger factors except fasting might in some way be related to a changed thermal stability of the mutated enzyme. It could be speculated that even exposure to cold might provoke symptoms, probably because of increased intramuscular temperature due to compensatory mitochondrial heat production. This is based on the observation that exposure to cold stimulates thermogenesis by increased mitochondrial metabolic rate and increased total energy expenditure not only in brown adipose tissue but also in rodent and human skeletal muscle and in bird plasma. ${ }^{17-19}$

The data reveal that the S113L mutation impairs the kinetic stability of human CPT II at increased temperatures. This is consistent with the lower heat resistance of the mutated enzyme in cultured fibroblasts. ${ }^{4}$ The results are also consistent with the MD simulations of the S113L variant, which show an increase in the flexibility of some residues at $40^{\circ} \mathrm{C}$, especially the residues in the vicinity of the mutation site. This in turn might cause a change in the conformational state of the mutated enzyme, resulting in a decreased thermal stability. 
Preincubation of the enzymes with the native substrate palmitoyl-CoA at $40^{\circ} \mathrm{C}$ before the addition of $\mathrm{L}$-carnitine further increased the thermal inactivation rate of CPT II, which was more pronounced for the variant than for the wild-type. The mechanism of this destabilizing effect and its pathophysiologic impact remain enigmatic.

Acyl-L-carnitines with more than 10 carbons in the acyl side-chain stabilized the variant $S 113 \mathrm{~L}$ against the temperature-induced inactivation. The stabilizing effect occurred only when the enzyme was preincubated with acyl-L-carnitine before starting the assay. A possible explanation for this stabilization is the formation of a stabilized binary complex after preincubation of the apoenzyme of CPT II with acyl (palmitoyl)-L-carnitine.

It has been shown that administration of a bolus of middle-chain fatty acids just before intensive exercise might prevent attacks of myoglobinuria in CPT II deficiency. ${ }^{20}$ Increased middle-chain acyl-CoA levels might lead to an increase of middle-chain acyl-L-carnitines. This will help not only to provide the required energy but also to stabilize this essential enzyme against inactivation.

However, there is not only a stabilizing effect by long-chain acyl-L-carnitine but also a progressively inhibiting effect on CPT II activity. In contrast to the stabilization by preincubation of the enzyme with acyl(palmitoyl)-L-carnitine, this inhibitory effect was observed only when the enzyme was simultaneously exposed to the substrates palmitoyl-CoA, palmitoylL-carnitine, and L-carnitine. The formation of a stabilized binary complex of the apoenzyme of CPT II with acyl(palmitoyl)-L-carnitine might be prevented by this simultaneous exposure. Under this condition, acyl(palmitoyl)-L-carnitine will impair the enzymatic turnover by product inhibition.

Both effects (inhibition and stabilization of the enzyme) by palmitoyl-L-carnitine were more pronounced for the S113L variant than for the wild-type, which further supports the view of an abnormal regulation of the mutated enzyme. ${ }^{21}$

Fasting is another trigger factor for attacks in CPT II-deficient patients. It is characterized by a decrease of free L-carnitine and an increase in acyl-Lcarnitine level in plasma. ${ }^{22,23}$ In the present study, the simultaneous addition of palmitoyl-L-carnitine to the assay might mimic this effect. The preincubation of middle- and long-chain acyl-L-carnitines before starting the assay, however, led to stabilization of the enzyme against thermal inactivation. Thus, acyl-L-carnitines can exert both effects (stabilization and inhibition) in vitro. It can be hypothesized that in vivo the time profile of changes in substrate concentration might determine which of these effects will prevail. In serum of CPT
II-deficient patients, the concentration of longchain acyl-L-carnitines is persistently elevated, even between the attacks. This can be used as a marker for diagnosis of this enzyme disorder. ${ }^{24}$ However, this might also exert the stabilizing effect in most physiologically relevant situations. Thus, the attacks might occur only when this mechanism is counteracted in extreme situations, such as by severe fever or under extreme dietary conditions with rapid increase of palmitoyl-L-carnitine concentrations (inhibition effect). Both aspects might explain the rare occurrence of attacks caused by the $S 113 \mathrm{~L}$ variant of CPT II deficiency. The biochemical consequences of other CPT II mutations have to be characterized in separate future studies.

\section{AUTHOR CONTRIBUTIONS}

L. Motlagh designed and performed the experiments and wrote the manuscript. R. Golbik designed and performed the experiments and wrote the manuscript. W. Sippl designed and performed the experiments and wrote the manuscript. S. Zierz designed the experiments and wrote the manuscript.

\section{ACKNOWLEDGMENT}

The authors thank Dr. Dina Robaa for carrying out molecular dynamics from the Institute of Pharmacy, Martin Luther University HalleWittenberg. We also thank Prof. Dr. Sven-Erik Behrens from the Institute of Biochemistry and Biotechnology, Martin Luther University HalleWittenberg; Prof. Dr. Marcus Deschauer and Dr. Pushpa Raj Joshi from the Department of Neurology, Martin Luther University HalleWittenberg; and Prof. Dr. Reinhard Neubert from the Institute of Pharmacy, Martin Luther University Halle-Wittenberg for providing excellent discussion and support.

\section{STUDY FUNDING}

No targeted funding reported.

\section{DISCLOSURE}

Dr. L. Motlagh and Dr. R. Golbik report no disclosures. Prof. W. Sippl has served on the scientific advisory board of the Journal of Computer Aided Molecular Design and has received research support from EU FP7 (“A-PARADDISE” EC-GA no. 602080) DFG Germany. Prof. S. Zierz has received speaker honoraria from Genzyme, Germany. Go to Neurology.org/ng for full disclosure forms.

Received April 15, 2015. Accepted in final form January 4, 2016.

\section{REFERENCES}

1. McGarry JD, Brown NF. The mitochondrial carnitine palmitoyltransferase system. From concept to molecular analysis. Eur J Biochem 1997;244:1-14.

2. Bonnefont JP, Djouadi F, Prip-Buus C, Gobin S, Munnich A, Bastin J. Carnitine palmitoyltransferases 1 and 2: biochemical, molecular and medical aspects. Mol Aspects Med 2004;25:495-520.

3. Joshi PR, Deschauer M, Zierz S. Carnitine palmitoyltransferase II (CPT II) deficiency: genotype-phenotype analysis of 50 patients. J Neurol Sci 2014;338:107-111.

4. Olpin SE, Afifi A, Clark S, et al. Mutation and biochemical analysis in carnitine palmitoyltransferase type II (CPT II) deficiency. J Inherit Metab Dis 2003;26: 543-557.

5. Fanin M, Anichini A, Cassandrini D, et al. Allelic and phenotypic heterogeneity in 49 Italian patients with the 
muscle form of CPT-II deficiency. Clin Genet 2012;82: 232-239.

6. Zierz S. Limited trypsin proteolysis renders carnitine palmitoyltransferase insensitive to inhibition by malonyl-CoA in patients with muscle carnitine palmitoyltransferase deficiency. Clin Investig 1994;72:957-960.

7. Lehmann D, Zierz S. Normal protein content but abnormally inhibited enzyme activity in muscle carnitine palmitoyltransferase II deficiency. J Neurol Sci 2014;339:183-188.

8. Motlagh L, Golbik R, Sippl W, Zierz S. Malony-CoA inhibits the S113L variant of carnitine-palmitoyltransferase II. Biochim Biophys Acta 2016;1861:34-40.

9. Taroni F, Verderio E, Dworzak F, Willems PJ, Cavadini P, DiDonato S. Identification of a common mutation in the carnitine palmitoyltransferase II gene in familial recurrent myoglobinuria patients. Nat Genet 1993;4:314-320.

10. Verderio E, Cavadini P, Montermini L, et al. Carnitine palmitoyltransferase II deficiency: structure of the gene and characterization of two novel disease-causing mutations. Hum Mol Genet 1995;4:19-29.

11. Rufer AC, Thoma R, Benz J, et al. The crystal structure of carnitine palmitoyltransferase 2 and implications for diabetes treatment. Structure 2006;14:713-723.

12. Ellman GL. A colorimetric method for determining low concentrations of mercaptans. Arch Biochem Biophys 1958;74:443-450.

13. Molecular Operating Environment (MOE), 2013.08. Montreal: Chemical Computing Group Inc.; 2015.

14. Sali A, Blundell TL. Comparative protein modelling by satisfaction of spatial restraints. J Mol Biol 1993;234: 779-815.

15. Case D, Darden T, Cheatham TE III, et al. AMBER 12. San Francisco: University of California; 2012.
16. Jones G, Willett P, Glen RC, Leach AR, Taylor R. Development and validation of a genetic algorithm for flexible docking. J Mol Biol 1997;267:727-748.

17. Stier A, Massemin S, Criscuolo F. Chronic mitochondrial uncoupling treatment prevents acute cold-induced oxidative stress in birds. J Comp Physiol B 2014;184:10211029.

18. Lim S, Honek J, Xue Y, et al. Cold-induced activation of brown adipose tissue and adipose angiogenesis in mice. Nat Protoc 2012;7:606-615.

19. van den Berg SA, van Marken Lichtenbelt W, van Dijk KW, Schrauwen P. Skeletal muscle mitochondrial uncoupling, adaptive thermogenesis and energy expenditure. Curr Opin Clin Nutr Metab Care 2011;14:243249.

20. Tucci S, Primassin S, Ter Veld F, Spiekerkoetter U. Medium-chain triglycerides impair lipid metabolism and induce hepatic steatosis in very long-chain acyl-CoA dehydrogenase (VLCAD)-deficient mice. Mol Genet Metab 2010;101:40-47.

21. Zierz S, Engel AG. Regulatory properties of a mutant carnitine palmitoyltransferase in human skeletal muscle. Eur J Biochem 1985;149:207-214.

22. Frohlich J, Seccombe DW, Hahn P, Dodek P, Hynie I. Effect of fasting on free and esterified carnitine levels in human serum and urine: correlation with serum levels of free fatty acids and beta-hydroxybutyrate. Metabolism 1978;27:555-561.

23. Hoppel CL, Genuth SM. Carnitine metabolism in normal-weight and obese human subjects during fasting. Am J Physiol 1980;238:E409-E415.

24. Gempel K, Kiechl S, Hofmann S, et al. Screening for carnitine palmitoyltransferase II deficiency by tandem mass spectrometry. J Inherit Metab Dis 2002;25:17-27. 


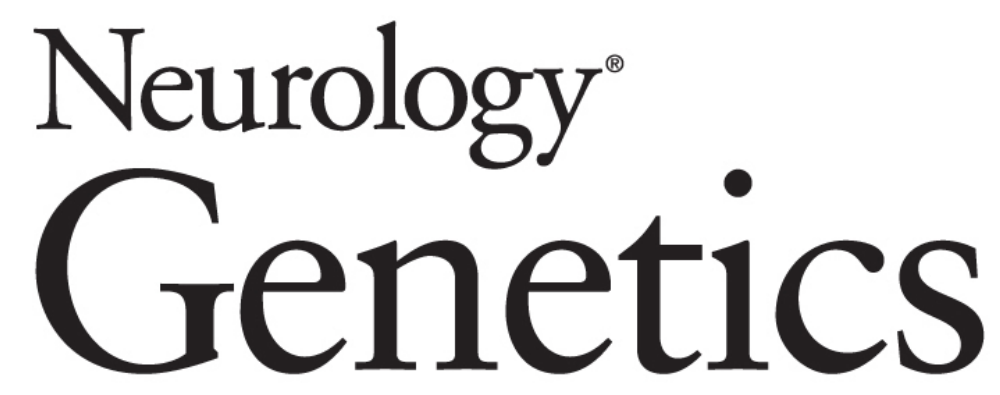

Stabilization of the thermolabile variant S113L of carnitine palmitoyltransferase II Leila Motlagh, Ralph Golbik, Wolfgang Sippl, et al.

Neurol Genet 2016;2;

DOI 10.1212/NXG.0000000000000053

This information is current as of February 25, 2016

\begin{abstract}
Updated Information \& Services

including high resolution figures, can be found at: http://ng.neurology.org/content/2/2/e53.full.html

Supplementary Material

Supplementary material can be found at: http://ng.neurology.org/content/supp1/2016/02/25/2.2.e53.DC1

References

This article cites 22 articles, 0 of which you can access for free at: http://ng.neurology.org/content/2/2/e53.full.html\#\#ref-list-1

Subspecialty Collections

This article, along with others on similar topics, appears in the following collection(s):

\section{All Neuromuscular Disease}

http://ng.neurology.org//cgi/collection/all_neuromuscular_disease Metabolic disease (inherited)

http://ng.neurology.org//cgi/collection/metabolic_disease_inherited

Permissions \& Licensing

Information about reproducing this article in parts (figures,tables) or in its entirety can be found online at:

http://ng.neurology.org/misc/about.xhtml\#permissions

Reprints

Information about ordering reprints can be found online: http://ng.neurology.org/misc/addir.xhtml\#reprintsus
\end{abstract}

Neurol Genet is an official journal of the American Academy of Neurology. Published since April 2015, it is an open-access, online-only, continuous publication journal. Copyright ( 2016 American Academy of Neurology. All rights reserved. Online ISSN: 2376-7839.

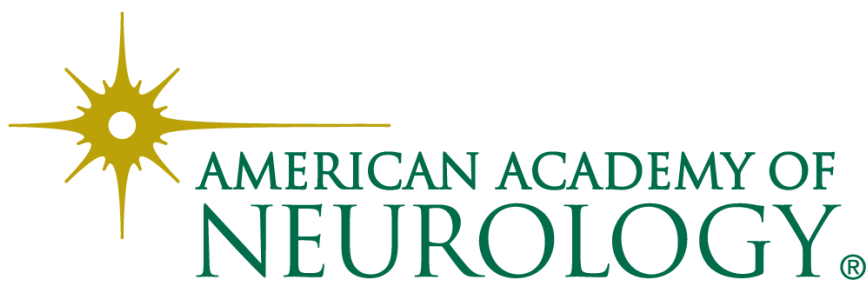

